\title{
Worth the Wait: Determinants of Ministerial Appointment in Canada, 1935-2008
}

\author{
MATTHEW Kerby Memorial University of Newfoundland
}

\section{Introduction}

The exploration of ministerial careers has attracted considerable attention among political scientists in recent years (Dewan and Dowding, 2005; Dowding and Kang, 1998; Huber and Martinez-Gallardo, 2004, 2008; Kam, 2006; Kam and Indridason, 2005; Laver and Shepsle, 1994; Sutherland, 1991a; Woodhouse, 1993) The purpose of this article is to present a new perspective on a burgeoning area of study by focusing on ministerial appointments rather than the determinants of ministerial exit or survival. This article introduces an original dataset of ministerial appointments for a single country, Canada, for the period 1935-2008. This dataset serves as the foundation for an event history model that highlights the causal mechanisms that underlie the ministerial appointment process while simultaneously considering the effects of time. The results of the event history analysis systematically confirm many commonly held assumptions regarding cabinet appointments in Canada; they emphasize the particular significance of gender and legal training as well as previous ministerial experience and leadership challenger status as characteristics that accelerate an appointment to cabinet. The article concludes with recommendations for continued research in this field of study.

Some certainties can be put assumed when discussing ministerial appointments in Canada. First, most elected representatives to the House of Commons are ambitious and would welcome a seat at the cabinet table.

Acknowledgments: The author would like to thank Kenneth Benoit, Keith Dowding, Patrick Dumont, Kelly Blidook, Eoin O'Malley, and Denise Ledoux, as well as the editors and anonymous reviewers of the CJPS, for their comments and suggestions.

Matthew Kerby, Department of Political Science, Memorial University of Newfoundland, St. John's, Newfoundland and Labrador, A1C 5S7, Canada, kerbym@mun.ca. 
Given the executive-centred nature of Canada's parliamentary system, opportunities for significant influence in policy are limited to those individuals in or close to the political executive. The attractiveness of a cabinet career is almost self-evident. Government policy and legislation are initiated in cabinet or cabinet committees. Additionally, a cabinet position provides an MP with the opportunity to develop a national reputation and profile. Cabinet is the ultimate goal of every ambitious federal politician. A seat at the federal cabinet table, therefore, represents the only chair that allows an individual the opportunity to satisfy both political and policy ambition. (Docherty, 1997: 95-96)

We also know that prime ministers have found the cabinet appointment process to be distasteful: despite his early moniker as a "cabinet maker," Sir John A. Macdonald nearly gave up in frustration when faced with the task of assembling his first cabinet; John Diefenbaker once remarked that he had to compose a cabinet which consisted of his political enemies (Punnett, 1977: 56, 63). More recent portrayals come off as less stressful but they nevertheless emphasize the variety of considerations taken into account when forming a cabinet (Campbell, 1996: 31720; Chrétien, 2007: 23-28; Mulroney, 2007: 315-19). ${ }^{1}$ Anecdotal evidence presents the cabinet formation process to be a witch's cauldron where practical, constitutional, representational, party and personal priorities compete (Goldenberg, 2006; Nielsen, 1989).

The academic literature in Canada pays considerable deference to the subject of cabinet appointment. Indeed, the classic and contemporary tomes of Canadian political science (Dawson and Dawson, 1989; Franks, 1987; Mallory, 1984; Porter, 1965; Savoie, 1999) all expand on the subject. The conventional wisdom highlights a number of core tropes: prime ministers hold significant power vis-à-vis aspiring ministers as they have the exclusive authority to appoint and dismiss ministers. However, this power is constrained by the prime minister's limited pool of candidates, high levels of legislative turnover which render many potential ministers inexperienced and accident prone, party considerations, and political principles which demand a minimal, yet unspecified, level of regional, linguistic, gender and ethnic representation (Heard, 1991: 49-50).

Despite the oft-repeated discussions, it has been over 35 years since Matheson (1976) and Punnett (1977) provided what are the most comprehensive descriptions of the Canadian federal cabinet and, with few exceptions, development has yet to expand beyond these contributions. Issues put forward in the comparative literature on ministerial survival, which pertain to the discussion of ministerial appointments, have yet to be systematically addressed or tested in the Canadian literature (Dewan and Dowding, 2005; Dewan and Mayatt, 2007; Huber and MartinezGallardo, 2004, 2008; Kam, 2006; Kam and Indridason, 2005). ${ }^{2}$

While this article does not delve too deeply into theoretical waters, it does provide substance to explore and expand the comparative litera- 
Abstract. The subject of ministerial career paths is neglected in the Canadian political science canon. The existing literature, data and methods are for the most part descriptive and require updating. This article addresses this deficit by focusing on the topic of ministerial appointments in the Canadian federal parliament. An event history model is developed to estimate the "hazard" of ministerial appointment for all government party members of Parliament for the period 1935-2008. Existing theories and explanations for ministerial appointments and their relationship to constitutional conventions and political principles are systematically tested using a series of variables identified in the Canadian and comparative literature. The paper concludes with recommendations for further research and integration with complementary country-specific and comparative research programs in the field of ministerial career paths.

Résumé. Le parcours de carrière ministérielle est un sujet négligé dans la convention de la science politique canadienne. La littérature, les données et les méthodes existantes sont majoritairement descriptives et requièrent une mise à jour. Cet article tente de combler cette lacune en étudiant les nominations ministérielles au gouvernement fédéral canadien. Un modèle de survie couvrant la période de 1935 à 2008 est mis au point afin d'évaluer le risque des nominations ministérielles pour tous les députés du parti politique au gouvernement. Les théories et interprétations actuellement utilisées pour déterminer les nominations ministérielles ainsi que leur affinité avec les conventions constitutionnelles et les préceptes politiques sont méthodiquement analysées à l'aide d'une suite de données reconnues dans la littérature canadienne et comparative. Finalement le document préconise la poursuite des recherches et un rapprochement avec les programmes de recherche comparatifs et propres au pays en matière de parcours de carrière ministérielle.

ture while simultaneously adding depth to the Canadian case. The first matter to address relates to data. We cannot begin to address the causes of ministerial appointment unless we extend our analysis beyond those MPs who are appointed to cabinet by including those MPs who have the possibility of being appointed but were not. Failure to do so invites selection bias on the dependent variable. This article overcomes the hurdle by compiling career path data on all government party MPs who make up the pool of potential cabinet ministers: those who are appointed as well as those who are not. The dataset is also expansive: it begins with Mackenzie King's 1935-1947 ministry and concludes during the Harper ministry in the summer of 2008. The second matter entails an assessment of the changing importance of individual MP attributes and political conventions and imperatives over time. In order to address this matter, the dataset is organized longitudinally and then used to inform an event history model of ministerial appointment which highlights the relative importance of various personal and contextual characteristics.

Although appointment considerations vary by prime minister and within ministries, prime ministers still have to choose whom to appoint and whom to leave on the backbenches. This article takes the perspective that those government party MPs who are appointed sooner rather than later can be viewed as "more suitable" at that point in time than those who are left behind. "More suitable" may not necessarily translate into "more skilled" or "more experienced." The speed of appointment simply reflects the prime minister's preferences, political or conventional neces- 
sities as well as the constraints of the day. ${ }^{3}$ No matter the rationale, the amount of time it takes for MPs to be appointed to cabinet can serve as an indicator of their suitability. At the extreme ends of the suitability spectrum we find those ministers who were appointed to cabinet without having first secured a seat in the House of Commons; they may be considered "most suitable" whereas permanent backbenchers may be regarded as the least suitable or needed in cabinet. Nevertheless a permanent backbencher's appointment to cabinet may be fast-tracked due to changing political circumstances or an unexpected crisis. The goal of this article is to provide the first systematic picture of the characteristics and circumstances that contribute to ministerial appointment.

The characteristics that accelerate ministerial appointment are divided into two categories: personal and political. This article argues that the personal characteristics that MPs bring with them when they are elected to the House of Commons (gender, university education, and legal training) affect the waiting time prior to cabinet appointment. Additional characteristics acquired once elected also have an impact on the speed of appointment. These characteristics include previous ministerial experience, margin of victory, and leadership challenger status. Contextual political factors such as the government party's strength in a MP's region, government majority size and prime ministerial term are also hypothesized to have an effect.

The remainder of the article proceeds as follows. Section 2 sets out the methodology while section 3 describes the data used to build a model of ministerial appointments; this section also presents the event history model of ministerial appointment. Section 4 presents the model results and is followed by section 5 which consists of concluding remarks and suggestions for future research.

\section{Method}

Drawing on methodological developments made in the government and ministerial survival literatures (Berlinski et al., 2007; Huber and MartinezGallardo, 2008; King et al., 1990), this study employs an event history model to ascertain the determinants of ministerial appointment. It differs from both the government and ministerial survival literatures in that it focuses on the time that a government party MP spends on the backbenches prior to cabinet appointment rather than the time to ministerial exit or government termination. Event history models are particularly useful when examining phenomena where duration and the transition from one state to another are the subjects of investigation; they are a more appropriate set of tools than ordinary least squares regression due to their ability to accommodate censored data as well as the violation of the 
assumption of normally distributed errors which typically arises when working with time-to-event data (Box-Steffensmeier and Jones, 2004: 15-17).

A key element in event history analysis is the hazard rate, which refers to the instantaneous probability that an individual will experience an event at a point in time given that the individual has "survived" up to that point in time. The hazard rate is expressed as

$$
h(t)=\lim _{\Delta t \rightarrow 0} \frac{\operatorname{Pr}(t \leq T \leq t+\Delta t \mid T \geq t)}{\Delta t}
$$

which is the probability that an individual will survive until time $t$ given that they have not experienced an event up to that point in time. By focusing on the hazard rate one is able to ask, "What is the likelihood that the prime minister will appoint a government party MP to cabinet at any point in time since the MP became a sitting member of the government party, given how long the MP has served in the government party as a backbencher?"

A useful feature of event history models relates to their ability to assume different parametric shapes for the hazard rate. Depending on the phenomenon under investigation one might assume that the hazard rate increases, decreases, or remains constant as time progresses; one can then assign a parametric shape to the hazard rate. However, assigning a parametric shape to the hazard function can be difficult when working with social and political data because the shape of the hazard may not be obvious. For this reason, most political scientists who use event history models choose to employ a Cox proportional hazards specification. Cox proportional hazard models are particularly useful when there are no ex ante assumptions about the parametric shape of the distribution of time of an individual's risk of experiencing a terminal event. Cox proportional hazard models have been widely employed in the social sciences and by political scientists in particular. The Cox proportional hazards model of ministerial appointment can be expressed as

$$
h_{i}(t)=h_{0}(t) \exp \left(\beta^{\prime} \mathrm{X}\right)
$$

where $h_{0}(t)$ is a government party MP's baseline hazard at $t ;\left(\beta^{\prime} \mathrm{X}\right)$ are the covariates and regression parameters characteristics which may affect the MP's durability. The purpose of the event history model then is to relate government party MPs' individual and political characteristics as well as the characteristics of the political environment in which they serve to the time it takes for them to be appointed to cabinet. Duration is recorded as the span that elapses from the time that a sitting MP becomes a member of the government party until he is appointed to cabinet or 
ceases to be a member of the government party in which case the MP is treated as censored.

\section{Data}

A unique dataset which records the time-to-appointment of every government party MP for the period 1935-2008 was assembled for the purposes of this study. ${ }^{4}$ In addition to the time spent prior to ministerial appointment, personal data were also collected on gender, university education, legal training, and age. Political characteristics, such as previous ministerial experience, margin of victory in the last contested election, leadership challenger status, the percentage of seats held by the government party in an MP's region, and the size of the government party, were also collected and recorded. The dataset consists of information for 2688 government party MPs of whom 401 were appointed to cabinet. These 2688 government party MPs represent 1684 individuals. ${ }^{5}$ Of these, 308 have been appointed to cabinet at least once while 30 of the 124 women who served in the government party were appointed to cabinet. Of these, 306 government party MPs have legal training while 675 possess a university education. The mean age of a government party MP is 50 as is the mean age of a minister on the date of their appointment to cabinet.

Table 1 presents the variable descriptions and descriptive statistics for those government party MPs appointed to cabinet. Tables 2 through 5 present the same data when broken down by ministry. Some preliminary observations are worth highlighting. A mean duration prior to cabinet appointment of 4.5 months can be explained by the majority of appointments taking place at the beginning of a ministry's first term. Ministries that display longer durations prior to appointment are those that are headed by long-serving prime ministers. These ministries provide more opportunities for government party MPs who are not appointed in the first term to be appointed at a later date.

The proportion of female cabinet appointees ranges from zero to 26 per cent and has increased over the period under investigation. The figure hovers above the proportion of female government party MPs as well as the proportion of seats held by all women in the House of Commons. ${ }^{6}$ Conservative prime ministers appear to appoint a slightly higher proportion of women (14 per cent) to cabinet than their Liberal counterparts (12 per cent).

The data reveal that the proportion of cabinet appointees with legal training reached its apex during the Pearson ministry (67 per cent) and since then has been gradually declining. Porter's observation that lawyers "constitute the high priesthood of the political system" in Canada may not be as true in 2008 as it was during the Pearson years (Porter, 
TABLE 1

Variables and Descriptive Statistics

\begin{tabular}{|c|c|c|c|}
\hline Variable & Definition & Mean & SD \\
\hline Duration & $\begin{array}{l}\text { Government backbench MP duration measured } \\
\text { in months. Failure is defined as appointment to } \\
\text { cabinet. MPs are treated as censored if they } \\
\text { reach the end of their duration without having } \\
\text { been appointed to cabinet. }\end{array}$ & 4.48 & 11.07 \\
\hline Female & $\begin{array}{l}\text { Dummy variable equal to one if female and } \\
\text { zero otherwise. }\end{array}$ & 0.12 & 0.33 \\
\hline Lawyer & $\begin{array}{l}\text { Dummy variable equal to one if MP has legal } \\
\text { training (LLB) and zero otherwise. }\end{array}$ & 0.44 & 0.50 \\
\hline University & $\begin{array}{l}\text { Dummy variable if MP holds a university } \\
\text { degree, zero if otherwise. }\end{array}$ & 0.68 & 0.47 \\
\hline Age & MP's age at appointment. & 49.78 & 7.91 \\
\hline $\begin{array}{l}\text { Previous Ministerial } \\
\text { Experience }\end{array}$ & $\begin{array}{l}\text { Dummy variable if MP has previous ministerial } \\
\text { experience. }\end{array}$ & 0.35 & 0.48 \\
\hline Margin of Victory & $\begin{array}{l}\text { Per cent difference between MP vote share and } \\
\text { runner-up in previous election. }\end{array}$ & 26.26 & 18.51 \\
\hline Leadership Challenger & $\begin{array}{l}\text { Dummy variable if MP was a challenger to PM } \\
\text { in party leadership race. }\end{array}$ & 0.03 & 0.17 \\
\hline \multicolumn{4}{|l|}{ Regional } \\
\hline Seat Share & $\begin{array}{l}\text { Share of seats held by the government party in } \\
\text { a MP's region (Western Canada, Ontario, } \\
\text { Quebec, Atlantic Canada) in percentages. }\end{array}$ & 61.69 & 24.33 \\
\hline Majority & $\begin{array}{l}\text { Share of the House of Commons commanded } \\
\text { by the governing party in percentages. }\end{array}$ & 55.05 & 10.82 \\
\hline Liberal & $\begin{array}{l}\text { Dummy variable if MP is a member of the } \\
\text { Liberal party, zero if otherwise. }\end{array}$ & & \\
\hline Term & Prime ministerial term. & & \\
\hline \multicolumn{2}{|l|}{ Subjects } & \multicolumn{2}{|c|}{$401 / 2688$} \\
\hline
\end{tabular}

1965: 392). Nevertheless, MPs with legal backgrounds still make up 44 per cent of all cabinet appointees, although that figure drops to 36 per cent for the post-Trudeau period. The drop in appointees with legal background is matched by a corresponding increase in the number of appointed cabinet ministers who possess a university education.

The mean age of cabinet appointment fluctuates over the period of investigation. St. Laurent and Martin appointed the "oldest" MPs to their cabinets while Trudeau and Turner appointed the youngest ministers. Research on cabinet appointments in the United Kingdom suggests that prime ministers are often caught between the Scylla and Charybdis of presiding over a cabinet that is too young and inexperienced or one that is 
TABLE 2

Descriptive Statistics by Ministry

\begin{tabular}{|c|c|c|c|c|c|c|c|c|}
\hline \multirow[b]{2}{*}{ Variable } & \multicolumn{2}{|c|}{$\begin{array}{c}\text { King } \\
1935-1948\end{array}$} & \multicolumn{2}{|c|}{$\begin{array}{l}\text { St. Laurent } \\
1948-1957\end{array}$} & \multicolumn{2}{|c|}{$\begin{array}{c}\text { Diefenbaker } \\
1957-1963\end{array}$} & \multicolumn{2}{|c|}{$\begin{array}{c}\text { Pearson } \\
1963-1968\end{array}$} \\
\hline & Mean & SD & Mean & SD & Mean & SD & Mean & SD \\
\hline Duration & 11 & 21 & 3.7 & 10 & 5 & 12 & 4.4 & 8.1 \\
\hline Female & 0 & 0 & 0 & 0 & 0.048 & 0.22 & 0.03 & 0.17 \\
\hline Lawyer & 0.16 & 0.37 & 0.26 & 0.45 & 0.48 & 0.51 & 0.67 & 0.48 \\
\hline University & 0.16 & 0.37 & 0.21 & 0.42 & 0.52 & 0.51 & 0.76 & 0.44 \\
\hline Age & 51 & 6.8 & 55 & 8.3 & 52 & 9.2 & 50 & 7.2 \\
\hline $\begin{array}{l}\text { Previous Ministerial } \\
\text { Experience }\end{array}$ & 0.42 & 0.51 & 0.89 & 0.32 & 0 & 0 & 0.15 & 0.36 \\
\hline Margin of Victory & 23 & 16 & 20 & 16 & 18 & 14 & 23 & 13 \\
\hline Leadership Challenger & 0 & 0 & 0.05 & 0.23 & 0.095 & 0.3 & 0.03 & 0.17 \\
\hline Regional Seat Share & 76 & 23 & 52 & 19 & 49 & 24 & 43 & 16 \\
\hline Majority & 69 & 7.3 & 52 & 8.3 & 47 & 13 & 47 & 8.4 \\
\hline Liberal & \multicolumn{2}{|c|}{ Yes } & \multicolumn{2}{|c|}{ Yes } & \multicolumn{2}{|c|}{ No } & \multicolumn{2}{|c|}{ Yes } \\
\hline Appointments & \multicolumn{2}{|c|}{19} & \multicolumn{2}{|c|}{19} & \multicolumn{2}{|c|}{21} & \multicolumn{2}{|c|}{33} \\
\hline
\end{tabular}

\section{TABLE 3}

Descriptive Statistics by Ministry

\begin{tabular}{|c|c|c|c|c|c|c|c|c|}
\hline \multirow[b]{2}{*}{ Variable } & \multicolumn{2}{|c|}{$\begin{array}{c}\text { Trudeau } \\
1968-1979\end{array}$} & \multicolumn{2}{|c|}{$\begin{array}{c}\text { Clark } \\
1979-1980\end{array}$} & \multicolumn{2}{|c|}{$\begin{array}{c}\text { Trudeau } \\
1980-1984\end{array}$} & \multicolumn{2}{|c|}{$\begin{array}{c}\text { Turner } \\
1984\end{array}$} \\
\hline & Mean & SD & Mean & $\mathrm{SD}$ & Mean & SD & Mean & SD \\
\hline Duration & 5.2 & 12 & 0.43 & 0 & 8.7 & 16 & 0.033 & 0 \\
\hline Female & 0.056 & 0.23 & 0.038 & 0.2 & 0.079 & 0.27 & 0.071 & 0.26 \\
\hline Lawyer & 0.56 & 0.5 & 0.58 & 0.5 & 0.55 & 0.5 & 0.54 & 0.51 \\
\hline University & 0.75 & 0.44 & 0.69 & 0.47 & 0.84 & 0.37 & 0.82 & 0.39 \\
\hline Age & 49 & 8 & 48 & 7 & 46 & 6.7 & 46 & 7.2 \\
\hline $\begin{array}{l}\text { Previous Ministerial } \\
\text { Experience }\end{array}$ & 0.56 & 0.5 & 0 & 0 & 0.42 & 0.5 & 0.82 & 0.39 \\
\hline Margin of Victory & 20 & 14 & 24 & 14 & 34 & 24 & 32 & 24 \\
\hline Leadership Challenger & 0.056 & 0.23 & 0 & 0 & 0 & 0 & 0.071 & 0.26 \\
\hline Regional Seat Share & 58 & 20 & 59 & 18 & 70 & 24 & 70 & 25 \\
\hline Majority & 51 & 4.4 & 48 & 0 & 52 & 0 & 52 & 0 \\
\hline Liberal & \multicolumn{2}{|c|}{ Yes } & \multicolumn{2}{|c|}{ No } & \multicolumn{2}{|c|}{ Yes } & \multicolumn{2}{|c|}{ Yes } \\
\hline Appointments & \multicolumn{2}{|c|}{36} & \multicolumn{2}{|c|}{26} & \multicolumn{2}{|c|}{38} & \multicolumn{2}{|c|}{28} \\
\hline
\end{tabular}

too old and stuffy (Alderman and Cross, 1985: 397-99). This does not appear to be the case for Canadian ministerial appointments where the mean age of MPs when appointed to cabinet resembles the mean age of all government party MPs. Indeed, the peaks and troughs in the data appear to follow changes in political generations. The mean age of appointment for the 1935-2008 period is 50.

Government party MPs' value in cabinet may be reflected by their previous cabinet experience. Cabinet experience serves as a key indica- 
TABLE 4

Descriptive Statistics by Ministry

\begin{tabular}{|c|c|c|c|c|c|c|c|c|}
\hline \multirow[b]{2}{*}{ Variable } & \multicolumn{2}{|c|}{$\begin{array}{c}\text { Mulroney } \\
1984-1993\end{array}$} & \multicolumn{2}{|c|}{$\begin{array}{c}\text { Campbell } \\
1993\end{array}$} & \multicolumn{2}{|c|}{$\begin{array}{c}\text { Chrétien } \\
1993-2003\end{array}$} & \multicolumn{2}{|c|}{$\begin{array}{c}\text { Martin } \\
2003-2006\end{array}$} \\
\hline & Mean & SD & Mean & SD & Mean & SD & Mean & SD \\
\hline Duration & 0.033 & 0 & 0.033 & 0 & 7 & 12 & 0.12 & 0.23 \\
\hline Female & 0.17 & 0.39 & 0.17 & 0.39 & 0.23 & 0.43 & 0.26 & 0.45 \\
\hline Lawyer & 0.3 & 0.47 & 0.3 & 0.47 & 0.42 & 0.5 & 0.33 & 0.48 \\
\hline University & 0.74 & 0.45 & 0.74 & 0.45 & 0.74 & 0.44 & 0.88 & 0.33 \\
\hline Age & 51 & 8 & 51 & 8 & 50 & 6.9 & 55 & 6.6 \\
\hline $\begin{array}{l}\text { Previous Ministerial } \\
\text { Experience }\end{array}$ & 0.7 & 0.47 & 0.7 & 0.47 & 0.19 & 0.4 & 0.29 & 0.46 \\
\hline Margin of Victory & 20 & 16 & 20 & 16 & 38 & 21 & 26 & 18 \\
\hline Leadership Challenger & 0.043 & 0.21 & 0.043 & 0.21 & 0.065 & 0.25 & 0 & 0 \\
\hline Regional Seat Share & 75 & 4 & 59 & 18 & 70 & 34 & 62 & 32 \\
\hline Majority & 57 & 0 & 57 & 0 & 59 & 2.6 & 56 & 4.4 \\
\hline Liberal & \multicolumn{2}{|c|}{ No } & \multicolumn{2}{|c|}{ No } & \multicolumn{2}{|c|}{ Yes } & \multicolumn{2}{|c|}{ Yes } \\
\hline Appointments & \multicolumn{2}{|c|}{55} & \multicolumn{2}{|c|}{23} & \multicolumn{2}{|c|}{31} & \multicolumn{2}{|c|}{42} \\
\hline
\end{tabular}

TABLE 5

Descriptive Statistics by Ministry

\begin{tabular}{lcc}
\hline \hline & \multicolumn{2}{c}{ Harper } \\
\cline { 2 - 3 } Variable & Mean & SD \\
\hline Duration & 3.3 & 5.3 \\
Female & 0.23 & 0.43 \\
Lawyer & 0.3 & 0.47 \\
University & 0.57 & 0.5 \\
Age & 50 & 9.3 \\
Previous Ministerial Experience & 0.033 & 0.18 \\
Margin of Victory & 26 & 19 \\
Leadership Challenger & 0.033 & 0.18 \\
Regional Seat Share & 45 & 21 \\
Majority & 40 & 0 \\
Liberal & \multicolumn{2}{c}{ No } \\
Appointments & \multicolumn{2}{c}{30} \\
\hline
\end{tabular}

tor that can distinguish amateur from experienced MPs (Atkinson and Docherty, 1992; Docherty, 1997; Sutherland, 1991a). It is therefore a rough gauge that prime ministers can use to estimate a MP's potential in government. One expects MPs who possess cabinet experience to have a higher hazard rate of cabinet appointment than those who do not. Ministerial appointees with previous cabinet experience account for 35 per cent of all ministerial appointments. Although when ministries characterized 
by a previously prolonged absence from government (Diefenbaker, Clark, and Harper) are dropped, then the proportion of experienced cabinet appointees increases to 43 per cent. These figures highlight a unique feature of many Canadian cabinets: the low level of previous parliamentary or ministerial experience among those who sit at the cabinet table. Sutherland (1991b) and White (1998) note that 14 per cent of all cabinet appointments made between 1949 and 1990 went to parliamentarians who possessed fewer than two years' total experience in the House of Commons. Compare this figure with the United Kingdom where ministers who served between 1945 and 1984 "had an average of 12.2 years of parliamentary experience before becoming ministers, and fewer than 10 per cent of ministers were appointed with less than five years' experience" (White, 1998: 377). The different levels of previous political experience held by ministers in Canada and the United Kingdom may be explained, in part, by size differences in the Canadian and British cabinets as well as the size of the parliamentary party selection pool which constrain or increase the number of choices available to the prime minister. Canadian ministerial selection is further complicated by the comparatively high levels of legislator turnover which further reduce the size of the pool of experienced and potential ministers (Matland and Studlar, 2004).

Anecdotal and journalistic accounts suggest that some ministers who are electorally successful may receive a cabinet seat as a reward for their electoral savvy. Maxime Bernier, one of only 11 Conservative MPs elected in the 2004 election in Quebec also won his seat with 67 per cent of the vote and a 47-point margin of victory over the runner-up prior to securing his place in Stephen Harper's cabinet. Margin of victory may also be strongly correlated with other less easily quantifiable variables than prime minister's value: political capital, constituency support, organizational ability, or finesse. On average, cabinet appointees have a margin of victory of 26 percentage points over their runners-up, which compares to 23 percentage points for those government party MPs who are not appointed to cabinet.

Prime ministers have good reasons to appoint party leadership competitors to cabinet. By doing so they are able to silence their most vocal critics in the party with collective ministerial responsibility. By extension, prime ministers can silence their rivals' supporters in the backbenches. As Carty observes, "It seems reasonable to conclude that running for party leadership pays well, even for losers. Almost all [leadership challengers] who were defeated have gone onto cabinet positions whenever that was an option" (1989: 125). The descriptive statistics show that leadership challengers make up only a small number of government party MPs; but 73 per cent of leadership challengers have been appointed to cabinet. Leadership challengers are identified as those individuals who appear on the final ballot at a party leadership convention. ${ }^{7}$ 
The representation principle dictates that all provinces, or at least all regions, should have a representative at the cabinet table. Strict adherence to the principle means that a perfectly representative cabinet should consist of a minimum of 10 ministers, one from each province (Heard, 1991: 49-50). However, the square peg of political principle does not always fit into the round hole of political reality. The obvious hurdle prime ministers face is what to do when the government party fails to elect a MP in a particular region or province. What this means for prime ministers is that the selection pool from which to choose may be so constrained as to not make it a choice at all.

The extent to which the representation principle can be realized is dictated by both legislative arithmetic as well as the political exigencies of the day. The considerations that inform appointments based on representation are varied, malleable and subject to modification over time. To try and encapsulate the multiplicity of factors into a single variable is difficult even if perfect data existed. A modest approach is adopted here whereby the representation principle is addressed with a variable that measures the proportion of seats that a government party holds in a MP's region (Western Canada, Ontario, Quebec, or Atlantic Canada). The logic argues that government party MPs who hail from regions where their party is underrepresented are more likely to be appointed to cabinet than MPs from overrepresented regions because prime ministers have a smaller selection pool to choose from. A similar assumption is adopted for the party majority variable. The expectation is that government party MPs who serve in "small" caucuses have a higher probability of being appointed to cabinet than MPs from "large" parliamentary parties on the grounds that prime ministers face a more restricted choice as a result of the smaller selection pool.

Figure 1 presents a graphical representation of the Kaplan Meier survivor function for all government party MPs under investigation. ${ }^{8}$ The graph shows that the survivor function drops precipitously in the first month and then quickly levels out, declining slowly over the course of five years at which point it levels out entirely. Figure 1 visually demonstrates the unfortunate state of affairs for government party MPs. Unless such MPs are appointed to the cabinet in the first month of their span, they run a high risk of remaining in a permanent selection pool of potential ministers with 88 per cent of the governing party caucus. The proportion of ministerial potentials only drops to 85 per cent after four years. The hard lesson for ambitious MPs is that unless they are appointed to cabinet in the first few months on the job, their chances of being appointed at all diminish rapidly.

Figure 2 elaborates on Figure 1 by breaking down the Kaplan Meier survivor function by individual and political characteristics. Figure 2 shows that personal characteristics, such as gender, legal background, and uni- 
FIGURE 1

Kaplan Meier Survivor Function for Government Party MPs: 1935-2008

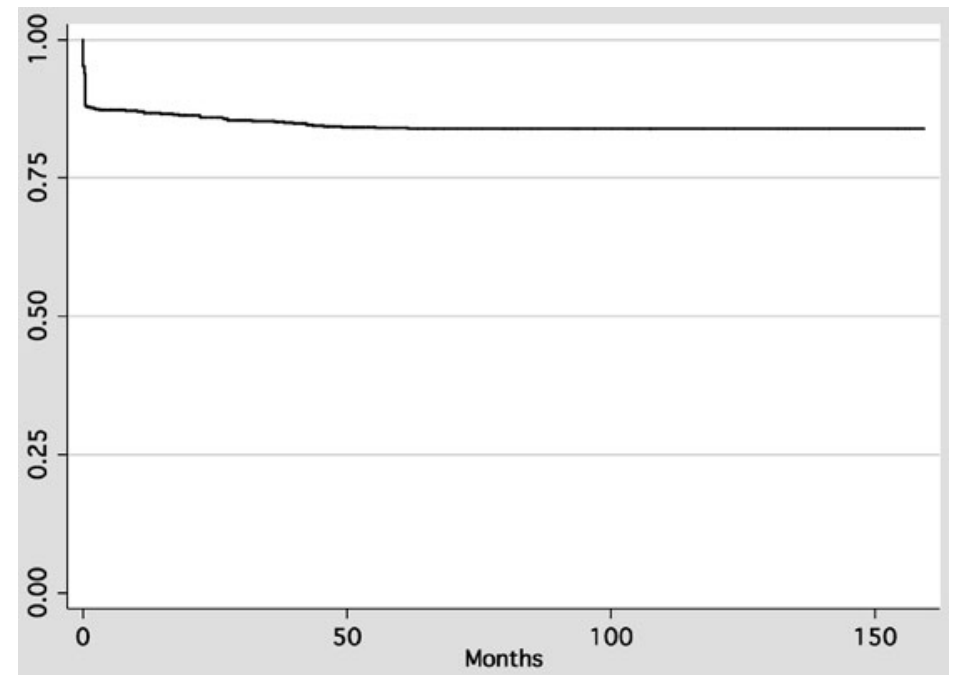

versity education, all reduce the survival rate of remaining in the backbenches. Party leadership contenders as well as those MPs who possess previous ministerial experience also have noticeably shorter survival rates when compared to those MPs who do not possess these attributes.

Characteristics related to the political environment also appear to have an impact on the survival function. Government party MPs from regions where their party is underrepresented have lower survival rates than those MPs who represent constituencies in regions where the government party holds more than a simple majority of seats. A similar relationship exists for the House of Commons as a whole: MPs who serve in a government party that holds a strong majority (greater than 55 per cent of the seats) have higher survival rates than MPs who serve in minority or slim majority governments. The term in which a MP serves also appears to have an effect. MPs who survive past the first government term can expect to see their survival rate increase. The survivor function, when broken down by political party, indicates that only a small difference exists between the parties when it comes to duration prior to appointment.

\section{Results}

Table 6 presents the event history model of ministerial appointment. Column 1 presents a model that includes government party MPs' personal 
FiguRE 2

Kaplan Meier Survivor Function or Government Party MPs:

1935-2008. Individual and Political Characteristics

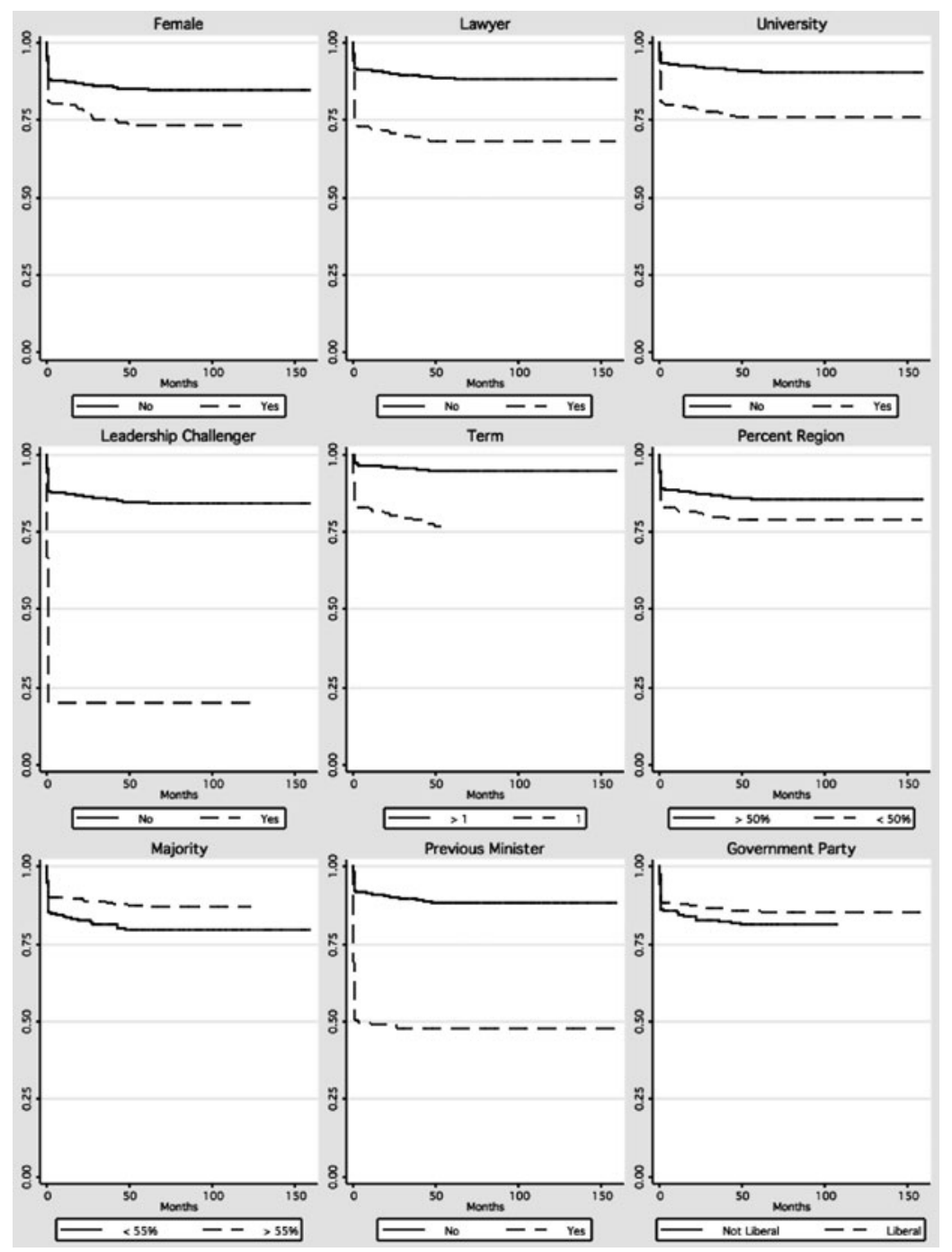

characteristics only. The model reveals that female government party MPs have a hazard rate that is slightly more than 50 per cent higher than their male colleagues on the backbenches. A legal background increases the hazard rate by 131 percentage points while a university education increases the hazard rate by 50 per cent. Government party MPs can expect the 
TABLE 6

Cox Proportional Hazards Model of Canadian Ministerial Appointment: 1935-2008

\begin{tabular}{lccc}
\hline \hline Variable & $(1)$ & $(2)$ & $(3)$ \\
\hline Female & $1.514^{\mathrm{c}}$ & $1.643^{\mathrm{c}}$ & $1.649^{\mathrm{c}}$ \\
& $(0.245)$ & $(0.267)$ & $(0.269)$ \\
Lawyer & $2.311^{\mathrm{c}}$ & $1.706^{\mathrm{c}}$ & $1.635^{\mathrm{c}}$ \\
& $(0.280)$ & $(0.214)$ & $(0.206)$ \\
University & $1.502^{\mathrm{c}}$ & $1.285^{\mathrm{a}}$ & $1.313^{\mathrm{b}}$ \\
& $(0.204)$ & $(0.177)$ & $(0.180)$ \\
Age & $1.411^{\mathrm{c}}$ & $1.342^{\mathrm{c}}$ & $1.348^{\mathrm{c}}$ \\
& $(0.087)$ & $(0.084)$ & $(0.084)$ \\
Age & & $0.997^{\mathrm{c}}$ & $0.997^{\mathrm{c}}$ \\
& $0.997^{\mathrm{c}}$ & $(0.001)$ & $(0.001)$ \\
Previous Ministerial Experience & $(0.001)$ & $4.733^{\mathrm{c}}$ & $4.360^{\mathrm{c}}$ \\
& & $(0.623)$ & $(0.580)$ \\
Margin of Victory & & $1.010^{\mathrm{c}}$ & $1.009^{\mathrm{c}}$ \\
& & $(0.003)$ & $(0.003)$ \\
Leadership Challenger & & $2.233^{\mathrm{c}}$ & $2.107^{\mathrm{b}}$ \\
& & $(0.686)$ & $(0.646)$ \\
Regional Seat Share & & $0.987^{\mathrm{c}}$ & $0.986^{\mathrm{c}}$ \\
& & $(0.003)$ & $(0.003)$ \\
Majority & & $0.981^{\mathrm{b}}$ & $0.976^{\mathrm{b}}$ \\
& & $(0.009)$ & $(0.011)$ \\
Second term & & $0.296^{\mathrm{c}}$ \\
Third term & & & $(0.075)$ \\
Fourth Term & & & $0.390^{\mathrm{b}}$ \\
Fifth Term & & & $(0.171)$ \\
& & & $0.295^{\mathrm{a}}$ \\
& & & $(0.194)$ \\
& & & 0.616 \\
& & & $(0.616)$ \\
& & &
\end{tabular}

Hazard ratios are reported. Standard errors in parentheses.

${ }^{\mathrm{a}} \mathrm{p} \leq .10$.

${ }^{b} \mathrm{p} \leq .05$.

${ }^{c} \mathrm{p} \leq .01$.

hazard of ministerial appointment to increase by 41 per cent for each year that they serve until they reach the age of 42 at which point the hazard levels off. All of the coefficients/hazard ratios in column 1 were statistically significant at the .01 level.

Column 2 extends the event history model to include political variables that pertain directly to a government party MP as well as the political environment in which he serves. The strongest effect can be seen with the previous minister variable. To put it succinctly, experience matters. Government party MPs who possess previous ministerial experience have a hazard rate that is 373 percentage points higher than their 
colleagues who lack this credential. Challengers to the party leadership possess a hazard rate that is 223 per cent higher than non-challengers. Finally, each additional percentage point in the government party MPs' electoral margin of victory raises the hazard by 1 per cent.

The remaining variables in column 2 relate to the political environment in which a government party MP serves. The representation principle has a strong influence on cabinet appointment. The model demonstrates that the hazard rate decreases by 1 per cent for each additional percentage point added to the proportion of seats held by the government party in a MP's region. A perverse logic suggests that ambitious MPs who yearn for a seat in the cabinet should hope that their party fairs poorly in their own region. Similarly, the hazard rate decreases by almost 2 per cent for each percentage point added to a government party's majority in the House of Commons. ${ }^{9}$ The personal characteristic variables are robust to the inclusion of the additional political variables with the exception of the university education variable, which is no longer statistically significant at the .05 level.

Column 3 duplicates the model in column 2 but conditions on prime ministerial term. The expectation here is that prime ministers will attempt to put together an ideal and durable cabinet at the beginning of their ministry. Subsequent modifications may take place but only if necessary. The implication for government party MPs is that their chances of cabinet appointment are severely diminished unless they are appointed in the first term. The hazard ratios for the term variable suggest that this is indeed the case. Government party MPs who remain backbenchers beyond the first-term experience hazard rates that range from 63 to 70 per cent lower than MPs who serve in a prime minister's first term. The personal and political variables in column 3 are robust to the inclusion of the term variable.

\section{Conclusion}

This study of ministerial appointments further expands our understanding of legislative and ministerial careers as well as prime ministerial power and decision making in Canada. The research presented here systematically confirms many widely held yet previously untested beliefs held by students of Canadian politics regarding the cabinet appointment process. Personal characteristics such as gender and legal training reduce the waiting time on the backbenches for government party MPs. These personal characteristics as well as age are robust across the three specifications presented above. Political characteristics are also significant and reflect the continuing relevance of political principles, such as the need for regional representation in the cabinet. The strongest effects can be seen 
with the ministerial experience and leadership challenger variables which highlight a prime minister's desire for stability and durability.

The initial model results are encouraging; nevertheless there is considerable room for improvement and expansion. In order to answer larger questions regarding the changing nature of representation in the Canadian cabinet, the dataset will have to extend further back in time, preferably to 1867 . Political principles do not change over night and if their evolution and changing impact on cabinet appointment are to be properly understood this project should begin at Confederation.

Certain missing variables also need to be developed, coded, and added to the model. The current analysis does not include a variable that considers legislative or cabinet experience at the provincial level. The Canadian political system lacks a linear career path that begins at the municipal, moves to the provincial, and ends at the federal level. Some suggest that those MPs who have previous provincial political experience have an advantage over their peers when it comes to the cabinet appointment process (Barrie and Gibbons, 1989). A similar argument can be made for those MPs who possess shadow cabinet or house leadership experience.

A second omission entails the absence of a variable that considers prime ministerial proximity. Among the many considerations that prime ministers must take into account, personal links - friendship, duty, reward and camaraderie - surely must play a part. Such a variable will be difficult to devise. These qualities are subjective and difficult to verify at the best of times, let alone code into a quantitative format. However, this challenge must not be ignored and a temporary or proxy variable based on the amount of time spent with the prime minister on the opposition or backbenches may be a useful starting point.

Third, the effects of public opinion should be integrated into the analysis. Research in the United Kingdom on cabinet shuffles and ministerial resignations has produced results that can be replicated in the Canadian context and used to test hypotheses not only on ministerial resignations but also ministerial appointments. As ministers leave the cabinet, new ministers need to be appointed as replacements. (Dewan and Dowding, 2005; Dewan and Mayatt, 2007). In addition, the study of cabinet appointments should be merged with the study of ministerial resignations in order to build a single model of cabinet and legislative career paths that simultaneously explains the causal mechanisms that drive both of these processes. By doing so, the phenomenon that is a ministerial career will be better understood.

\section{Notes}

1 This article uses the convention employed for principal-agent modeling in which the female pronoun is used for the principal and the male pronoun used for the agent. In 
this case, prime ministers are female and cabinet ministers and MPs are male unless referring to a specific individual.

2 Kam and Indridason's contributions are an exception.

3 Despite their status as "fathers of confederation," both D'Arcy McGee and Charles Tupper were passed over for inclusion in Macdonald's 1867 cabinet in order to accommodate religious and regional representational requirements.

4 Data were kindly made available by the Library of Parliament. Senators are not included in the dataset as they are not elected members of the House of Commons. Prime ministers are also excluded. Ministers appointed to cabinet prior to obtaining a seat in the House of Commons are not considered in the event history analysis until they their secure their seat; ministers without constituency who fail to win their seat are omitted from the analysis altogether.

5 The difference in the number of government party MPs and individuals arises from the repeat appearance of MPs across and within ministries. MPs who are appointed to cabinet, leave, and are then reappointed at a later date are treated as separate individuals although they share similar personal and experiential characteristics.

6 This study does not address the substantive quality of female representation in the cabinet or the House of Commons. For a detailed discussion on this subject see Studlar and Moncrief (1997), Davis (1997), Tremblay (1998) and the contributions to Arscott and Trimble (1997).

7 Despite their status as "leadership challengers," the remaining 27 per cent who were not appointed to cabinet (Charles Power, Harold Henderson, Tom Wappel, John Nunziata, and Shelia Copps) were not serious contenders in terms of their numerical support.

8 The survivor function $S(t)=\operatorname{Pr}(T \geq t)$ denotes the probability that a survival time $T$ is greater than or equal to $t$. The survivor function can also be understood as the proportion of units that survive past $t$. The Kaplan Meier survivor function is the nonparametric estimate of the survivor function $S(t)$.

9 I included a government party "size" variable coded as the ratio between cabinet size and government party caucus size. The variable proved to be statistically insignificant.

\section{References}

Alderman, R.K. and J.A. Cross. 1985. "The Reluctant Knife: Reflections on the Prime Minister's Power of Dismissal." Parliamentary Affairs 38: 387-408.

Arscott, Jane and Linda Trimble, ed. 1997. In The Presence of Women. Toronto: Harcourt Brace.

Atkinson, Michael M. and David C. Docherty. 1992. "Moving Right Along: The Roots of Amateurism in the Canadian House of Commons." Canadian Journal of Political Science 25: 295-318.

Barrie, Doreen and Roger Gibbons. 1989. "Parliamentary Careers in the Canadian Federal State." Canadian Journal of Political Science 22: 137-45.

Berlinski, Samuel, Torun Dewan and Keith Dowding. 2007. "The Length of Ministerial Tenure in the United Kingdom, 1945-97." British Journal of Political Science 37: $245-62$.

Box-Steffensmeier, Janet M. and Bradford S. Jones. 2004. Event History Modeling: A Guide for Social Scientists. Cambridge: Cambridge University Press.

Campbell, Kim. 1996. Time and Change: The Political Memoirs of Canada's First Woman Prime Minister. Toronto: Doubleday.

Carty, R.K. 1989. "Is There Political Life After Losing the Race?" Journal of Canadian Studies 24: 116-27.

Chrétien, Jean. 2007. My Years as Prime Minister. Toronto: Alfred A. Knopf Canada. 
Davis, Rebecca Howard. 1997. Women and Power in Parliamentary Democracies: Cabinet Appointments in Western Europe, 1968-1992. Lincoln NE: University of Nebraska Press.

Dawson, R. MacGregor and W.F. Dawson. 1989. Democratic Government in Canada. 5th ed., rev. Norman Ward. Toronto: University of Toronto Press.

Dewan, Torun and Keith Dowding. 2005. "The Corrective Effect of Ministerial Resignations on Government Popularity." American Journal of Political Science 49: $46-56$.

Dewan, Torun and David P. Mayatt. 2007. "Scandal, Protection, and Recovery in the Cabinet." American Political Science Review 101: 63-78.

Docherty, David C. 1997. Mr. Smith Goes to Ottawa: Life in the House of Commons. Vancouver: UBC Press.

Dowding, Keith and Won-Taek Kang. 1998. "Ministerial Resignations 1945-97.” Public Administration 76: 411-29.

Franks, C.E.S. 1987. The Parliament of Canada. Toronto: University of Toronto Press.

Goldenberg, Eddie. 2006. The Way It Works: Inside Ottawa. Toronto: McClelland \& Stewart.

Heard, Andrew. 1991. Canadian Constitutional Conventions: The Marriage of Law and Politics. Toronto: Oxford University Press.

Huber, John D. and Cecilia Martinez-Gallardo. 2004. "Cabinet Instability and the Accumulation of Experience: The French Fourth and Fifth Republics in Comparative Perspective." British Journal of Political Science 34: 27-48.

Huber, John D. and Cecilia Martinez-Gallardo. 2008. "Replacing Cabinet Ministers: Patterns of Ministerial Stability in Parliamentary Democracies." American Political Science Review 102: 169-80.

Kam, Christopher. 2006. "Demotion and Dissent in the Canadian Liberal Party." British Journal of Political Science 36: 561-74.

Kam, Christopher and Indridi Indridason. 2005. "The Timing of Cabinet Reshuffles in Five Westminster Parliamentary Systems." Legislative Studies Quarterly 30: 327-63.

King, Gary, James E. Alt, Nancy Burns and Michael Laver. 1990. "A Unified Model of Cabinet Dissolution in Parliamentary Democracies." American Journal of Political Science 34: 846-71.

Laver, Michael and Kenneth A. Shepsle, ed. 1994. Cabinet Ministers and Parliamentary Government. Cambridge: Cambridge University Press.

Mallory, J.R. 1984. The Structure of Canadian Government. Rev. ed. Toronto: Gage Publishing.

Matheson, W.A. 1976. The Prime Minister and the Cabinet. Toronto: Methuen.

Matland, Richard E. and Donley T. Studlar. 2004. "Determinants of Legislative Turnover: A Cross National Analysis." British Journal of Political Science 34: 87-108.

Mulroney, Brian. 2007. Memoirs. Toronto: McClelland \& Stewart Ltd.

Nielsen, Erik. 1989. The House Is Not a Home. Toronto: Macmillan.

Porter, John. 1965. The Vertical Mosaic: An Analysis of Social Class and Power in Canada. Toronto: University of Toronto Press.

Punnett, R.M. 1977. The Prime Minister in Canadian Government and Politics. Toronto: Macmillan of Canada.

Savoie, Donald J. 1999. Governing from the Centre: The Concentration of Power in Canadian Politics. Toronto: University of Toronto Press.

Studlar, Donley T. and Gary F. Moncrief. 1997. "The Recruitment of Women Cabinet Ministers in the Canadian Provinces." Governance: An International Journal of Policy and Administration 10: 67-81.

Sutherland, Sharon. 1991a. "Responsible Government and Ministerial Responsibility: Every Reform Is Its Own Problem." Canadian Journal of Political Science 24: 91-120. 
Sutherland, Sharon. 1991b. "The Consequences of Electoral Volatility: Inexperienced Ministers 1949-90.” In Representation, Integration and Political Parties, ed. Herman Bakvis. Toronto: Dundern Press.

Tremblay, Manon. 1998. "Do Female MPs Substantively Represent Women? A Study of Legislative Behaviour in Canada's 35th Parliament." Canadian Journal of Political Science 31: 435-65.

White, Graham. 1998. "Shorter Measure: The Changing Ministerial Career in Canada." Canadian Public Administration 41: 369-94.

Woodhouse, Diana. 1993. "Ministerial Responsibility in the 1990s: When Do Ministers Resign?” Parliamentary Affairs 46: 277-92. 